\title{
PEMATANGAN GONAD DAN PEMIJAHAN INDUK IKAN NAPOLEON (Cheilinus undulatus) DENGAN PERBANDINGAN SUMBER PROTEIN PAKAN YANG BERBEDA
}

\author{
Tatam Sutarmat dan Bejo Slamet
}

\begin{abstract}
ABSTRAK
Untuk pengembangan budi daya ikan napoleon, Cheilinus undulatus perlu disiapkan teknologi perbenihannya. Pada penelitian ini dilakukan uji coba pematangan gonad dan pemijahan induk ikan napoleon dengan perbandingan sumber protein yang berbeda. Induk napoleon betina yang digunakan dengan kisaran antara 2,8-4,6 kg/ekor dan panjang 53-63 cm: serta induk jantan dengan bobot 4,98-5,8 kg/ekor dan panjang total $67-68 \mathrm{~cm}$. Wadah penelitian menggunakan tiga buah tangki beton volume $50 \mathrm{~m}^{3}$, yang masing masing diisi dengan 5 ekor betina dan 1 ekor jantan. Pakan yang diberikan untuk tiap perlakuan adalah perbedaan perbandingan sumber protein pakan tepung ikan dan tepung cumi-cumi yaitu perlakuan $A=2: 1, B=1: 1$, dan $C=1: 2$. Berdasarkan data perkembangan gonad yang dilakukan setiap bulan dan data pemijahan, perlakuan $B$ memberikan hasil yang baik dengan tertingginya persentase tingkat pematangan gonad $(80 \%)$, frekuensi pemijahan dan jumlah telur yang dihasilkan. Hasil ini menunjukkan bahwa komponen nutrien pakan yang terkandung dalam tepung cumi-cumi mempunyai peranan penting dalam memacu pematangan gonad dan pemijahan induk serta telur yang dihasilkan.
\end{abstract}

\section{ABSTRACT: Gonad maturation and spawning of napoleon fish Cheilinus undulatus by dif- ferent ratios of food protein source. By: Tatam Sutarmat and Bejo Slamet}

\begin{abstract}
Napoleon fish is one of the most important marine species due to its high economic value. Aquaculture activities for this species could not develop well because of constramts of unavail. able seed. They experiment on maturation and spawning of napoleon fish used different ratios of protein source. Females 2.8-4.6 kg body weigh with 52- $63 \mathrm{~cm}$ total length and males of 4.98-5.8 $\mathrm{kg}$ body weight with $67-68 \mathrm{~cm}$ total length were reared in three $50 \mathrm{~m}^{3}$ concrete tanks. Five females, and one male were kept together in each tank. The experimental feeds experiment for broodstock were combinations of fish meal and squid with ratio of $A=2: 1, B=1: 1$ and $C=1: 2$. Based on monthly check gonad maturation and spawning, ratio of $B(1: 1)$ gamed the best result in term of $80 \%$ maturation stage and egg quality. The result suggests that nutrient content of squid meal has an important role to speed up maturation and egg quantity.
\end{abstract}

\section{KEYWORDS: $\quad$ napoleon fish, gonad maturation, spawning, protein}

\section{PENDAHULUAN}

Untuk memenuhi permintaan ekspor yang tinggi pada ikan napoleon, alternatif yang sangat memungkinkan untuk dilaksanakan adalah dengan membudidayakannya. Kendala utama yang dihadapi dalam pengembangan budi daya ikan napoleon, Cheilinus undulatus adalah tersedianya benih. Untuk pengembangan budi daya ikan ini perlu disiapkan teknologi pembenihannya. Keberhasilan suatu pembenihan sangat ditentukan oleh tersedianya induk yang cukup, baik jumlah, kualitas, dan keseragaman (Hardjamulia, 1988). Kualitas induk merupakan salah satu faktor yang sangat menentukan keberhasilan produksi benih. Dalam kegiatan pembenihan, ketersediaan induk matang gonad (jantan, betina) sangat diperlukan, hal ini untuk menjamin kesinambungan pasok benih untuk usaha budi daya.
Tingkat kematangan dan kualitas gonad yang dihasilkan sangat ditentukan oleh kualitas pakan yang diberikan. Pakan harus mempunyai komposisi khusus yang merupakan faktor penting dalam mendukung keberhasilan proses pematangan gonad dan pemijahan (Primavere, 1985). Penelitian pematangan gonad dan pemijahan induk ikan melalui pemberian pakan campuran ikan rucah dan cumi-cumi dari beberapa jenis ikan telah dilakukan antara lain pada kakap putih (Lates calcarifer) dan kakap merah (Lutjanus argentimaculatus) (Slamet et al., 1993); kerapu macan (Epinephelus fuscoguttatus) (Mayunar, 1995); kerapu bebek (Cromileptes altivelis) (Tridjoko et al., 1999); kerapu batik (Epinephelus microdon) (Giri et al., 1999); dan pada napoleon (Cheilinus undulatus) (Slamet et al., 1993; 1999). Hasil penelitian ikan napoleon tahun 1998/1999 menunjukkan bahwa formulasi pakan buatan moist pellet dengan perbandingan

\footnotetext{
*) Peneliti pada Balai Besar Riset Perikanan Budidaya Laut, Gondol
} 
tepung ikan dan tepung cumi 52:15 yang digunakan mampu menyetimulir perkembangan gonad ikan napoleon sampai memijah. Penelitian ini bertujuan untuk mempercepat proses pematangan gonad dan pemijahan induk ikan napoleon, serta memperbaiki mutu telur melalui perbaikan mutu pakan induk ikan napoleon.

\section{BAHAN DAN METODE}

Penelitian dilakukan selama tujuh bulan di Balai Besar Riset Perikanan Budidaya Laut Gondol, Bali. Induk didapatkan dari hasil penangkapan nelayan di sekitar perairan Madura, Kepulauan Kangean, dan NTB dengan kisaran bobot antara 3-6 kg. Calon induk yang digunakan dalam percobaan dipilih yang tidak cacat dan dalam kondisi sehat. Wadah penelitian menggunakan bak beton volume $50 \mathrm{~m}^{3}$ yang masing- mineral didasarkan atas komposisi yang dibuat oleh Shimeno et al. (1992).

Untuk merangsang nafsu makan, pada formulasi pakan buatan ditambah stimulan (Takeda, 1981). Sebagai bahan perekat digunakan CMC-Na dan tepung kanji. Formulasi dan komposisi selengkapnya dapat dilihat pada Tabel 1.

Pemberian pakan dilakukan 2 kali sehari pada pagi dan sore hari sampai kenyang. Setiap hari dilakukan pembersihan dasar bak dengan cara disipon. Setiap bulan dilakukan pengamatan terhadap bobot dan panjang induk serta perkembangan tingkat kematangan gonad melalui kanulasi menggunakan selang kateter, selanjutnya diamati di bawah mikroskop.

Peubah yang diamati meliputi perkembangan kematangan gonad, waktu pemijahan, diameter, dan

Tabel 1. Komposisi bahan dasar dan analisis proksimat dari pakan yang digunakan dalam penelitian

Table 1. Composition and proximate analysis of ingredient used in the experiment

\begin{tabular}{lccc}
\hline \multicolumn{1}{c}{ Bahan (Ingredient) } & Pakan A (Diet A) & Pakan B (Diet B) & Pakan C (Diet C) \\
\hline Tepung ikan (Fish meal) & 46 & 34.5 & 23 \\
Tepung cumi-cumi (Squid meal) & 23 & 34.5 & 46 \\
Minyak ikan (Fish oil) & 10 & 10 & 10 \\
Tepung terigu (Wheat flour) & 10 & 10 & 10 \\
Vitamin (Vitamin mix) & 3 & 3 & 3 \\
Mineral (Mineral mix) & 2.5 & 2.5 & 2.5 \\
Stimulan & 0.5 & 0.5 & 0.5 \\
Binder CMC-Na & 1.5 & 1.5 & 1.5 \\
Tepung kanji (Starch) & 3.5 & 3.5 & 3.3 \\
\hline \multicolumn{1}{c}{ Total } & 100 & 100 & 100 \\
\hline Komposisi pakan uji (\% bobot kering) (Feed composition) (\% dry basic) & \\
\hline Protein (Protein) & 44.5 & 46.10 & 47.5 \\
Lemak kasar (Crude fat) & 14.52 & 13.3 & 11.21 \\
Serat kasar (Crude fiber) & 6.07 & 5.98 & 5.56 \\
Abu (Ash) & 11.78 & 9.75 & 3262 \\
Energi (Energy)(kkal/kg diet) & 3358 & 3356 & 68.67 \\
Kalori (Calorie/protein ratio) & 75.46 & 72.84 & \\
\hline
\end{tabular}

masing diisi dengan 5 ekor betina dan 1 ekor jantan, dengan sistem sirkulasi air sebanyak $150 \%-300 \%$ total volume per hari dan diaerasi. Pakan yang digunakan adalah moist pellet dengan campuran tepung ikan dan tepung cumi-cumi (hasil terbaik penelitian tahun 1998-1999). Perlakuan perbedaan perbandingan sumber protein pakan tepung ikan dan tepung cumi-cumi yaitu $A=2: 1, B=1: 1$, dan $C=1: 2$ sebagai ulangan adalah individu induk. Sumber protein pakan buatan berasal dari tepung ikan dan tepung cumi-cumi, sumber karbohidrat dari tepung terigu, sumber lemak dari minyak ikan dan vitamin, serta jumlah telur, rasio pembuahan dan penetasan. Sebagai faktor penunjang, beberapa peubah kualitas air diukur satu kali seminggu.

\section{HASIL DAN BAHASAN}

Hasil analisis komposisi pakan menunjukkan bahwa pakan $\mathrm{C}$ mempunyai kadar protein tertinggi $(47,5 \%)$; disusul pakan B $(46,1 \%)$; dan pakan A $(44,5 \%)$. Kadar lemak tertinggi adalah pada pakan $A$ (14,52\%); diikuti pakan B (13,3\%); dan pakan C $(11,21$ $\%)$. 
Energi tertinggi terdapat pada pakan A (3.358), selanjutnya pakan B (3.356 kkal/ $/ \mathrm{kg})$, dan pakan C $(3.262 \mathrm{kkal} / \mathrm{kg})$. Dilihat dari keseimbangan unsur-unsur nutrisi (protein, lemak) maka pakan B memiliki nilai nutrisi terbaik, sedangkan pakan $\mathrm{C}$ walaupun memiliki nilai protein cukup tinggi tetapi ditinjau dari keseimbangan nilai nutrisinya adalah kurang seimbang.

Perkembangan gonad selama penelitian dapat dilihat pada Tabel 2. Pada penelitian sebelumnya diperlakukan induk napoleon saat gonad belum telihat (negatif) dan belum nampak sel telur maupun sperma. Hasil pengamatan selama 6 bulan percobaan berlangsung pada masing-masing perlakuan ternyata bervariasi. L.aju perkembangan gonad perlakuan $C$ lebih cepat dibandingkan dengan perlakuan A dan B, terlihat pada bulan ketiga (7 Oktober 1999) persentase yang matang mencapai $40 \%$, sedangkan pada perlakuan $\mathrm{A}$ dan $\mathrm{B}$ masing-masing $10 \%$. Pada bulan
Desember jumlah induk betina yang matang telur pada perlakuan $\mathrm{B}$ dan $\mathrm{C}$ sebanyak $80 \%$ dengan diameter telur berkisar antara $225-431 \mu \mathrm{m}$, maka perlakuan menunjukkan hasil yang terbaik bila dibandingkan dengan perlakuan $A$, yang matang telurnya hanya $60 \%$ dengan diameter telur 168-328 $\mu \mathrm{m}$. Sedangkan pada akhir percobaan (bulan Februari) jumlah induk matang gonad terbanyak pada perlakuan A dan B yaitu mencapai $100 \%$, sedangkan perlakuan C mencapai $80 \%$.

Pemijahan terjadi pada bulan Desember dimulai pada hari kelima - kedelapan bulan baru (tanggal 1316 ) dan bulan Januari dimulai pada hari ketiga - ketiga bulan baru dan pada bulan terang (tanggal 9-20) pada perlakuan $B$ dengan jumlah telur mencapai 1.084.000 butir (12 kali memijah), pada perlakuan $\mathrm{C}$ mencapai 610.000 butir ( 6 kali memijah), dan pada perlakuan $A$ yaitu 225.000 butir ( 3 kali pemijahan), untuk

Tabel 2. Persentase induk betina matang gonad dan diameter telur/oosit ( $\mathrm{mm}$ ) induk ikan napoleon selama percobaan

Table 2. Precent gonadal maturation and diameter oocyte of napoleon fish durung experiment

\begin{tabular}{|c|c|c|c|c|c|c|c|c|c|}
\hline $\begin{array}{l}\text { Perlakuan } \\
\text { Treatment }\end{array}$ & $\begin{array}{c}\text { Seks } \\
\text { Sex }\end{array}$ & BW/TL & 9-Aug & 2-Sep & 7.Oct & 3-Nov & 7-Des & 2-Jan & 3-Feb \\
\hline \multirow{6}{*}{ A } & 甲 & $2.8 / 53$ & - & - & - & - & & - & 100 \\
\hline & 우 & $3.1 / 56$ & -. & - & 50 & 80 & 168 & 203 & 200 \\
\hline & ㅇ & $4.5 / 62$ & - & 50 & 172 & 265 & 328 & 345 & 350 \\
\hline & ㅇ & $3.8 / 61$ & - & - & - & 125 & 281 & 352 & 200 \\
\hline & q & $3.7 / 59$ & - & - & - & - & - & 50 & 100 \\
\hline & $0^{x}$ & $5.1 / 66$ & - & - & - & - & - & $\therefore$ & - \\
\hline \multicolumn{2}{|c|}{ Mature (\%) } & & - & 10 & 40 & 60 & 60 & 60 & 100 \\
\hline \multirow{6}{*}{ B } & 웅 & $4.14 / 60$ & - & - & - & 187 & 430 & 250 & 150 \\
\hline & q & $4.52 / 63$ & - & - & - & 203 & 421 & - & 350 \\
\hline & ㅇ & $3.14 / 56$ & - & - & - & - & - & 390 & 400 \\
\hline & ㅇ & $3.02 / 57$ & - & - & 93 & 100 & 274 & 430 & 400 \\
\hline & q & $4.04 / 59$ & - & 50 & 156 & 281 & 250 & 359 & 350 \\
\hline & $0^{x}$ & $5.18 / 67$ & - & - & - & - & - & - & - \\
\hline \multicolumn{2}{|c|}{ Mature (\%) } & & - & 10 & 60 & 80 & 60 & 60 & 100 \\
\hline \multirow{6}{*}{ C } & 우 & $3.62 / 54$ & - & - & 100 & 187 & 265 & 420 & 200 \\
\hline & ㅇ & $3.76 / 61$ & - & - & 172 & 274 & 303 & 359 & 300 \\
\hline & 우 & $3.68 / 60$ & - & - & 140 & 286 & 396 & 225 & 350 \\
\hline & 우 & $3.78 / 57$ & - & - & - & 93 & 225 & 296 & 320 \\
\hline & q & $3.16 / 56$ & - & 50 & - & - & - & - & 50 \\
\hline & $0^{\pi}$ & $5.25 / 68$ & - & - & - & - & - & - & - \\
\hline \multicolumn{2}{|c|}{ Mature (\%) } & & - & 40 & 60 & 80 & 80 & 80 & 80 \\
\hline
\end{tabular}


selengkapnya dapat dilihat pada Tabel 3. Dari diameter telur yang dihasilkan terlihat bahwa terdapat perbedaan diameter telur di antara beberapa perlakuan. Diameter telur terbesar diperoleh dari perlakuaan B yaitu antara 625--734 $\mu \mathrm{m}$ dan perlakuan C antara 640$-703 \mu \mathrm{m}$. Demikian juga halnya dengan diameter butir minyak di mana perlakuan B menunjukkan yang tertinggi antara 125--172 $\mu \mathrm{m}$ dan perlakuan $\mathrm{C}$ antara 140--154 $\mu \mathrm{m}$. Dari hasil di atas dapat dilihat bahwa perlakuan B (perbandingan tepung ikan dan tepung cumi-cumi 1:1) menunjukkan hasil yang terbaik. Pada perlakuan $\mathrm{C}$ (perbandingan tepung ikan dan tepung cumi-cumi 1:2) persentase induk betina matang gonad sama, tetapi pemijahannya lebih kecil dibandingkan dengan perlakuan B. Dibandingkan dengan perlakuan $A$ (perbandingan tepung ikan dan tepung cumi 2:1), persentase induk betina matang lebih kecil dan tidak memijah dibandingkan dengan kedua periakuan.

Dari kenyataan ini diduga komponen nutrien cumi yang berperan penting dalam proses pematangan gonad dan pemijahan ikan napoleon ini yaitu komponen protein yang terkandung dalam cumi-cumi. Kandungan protein pakan pada perlakuan B dan C lebih tinggi dari perlakuan $A$ akibat adanya penambahan tepung cumi, di mana secara umum kandungan protein tepung cumi memang lebih tinggi dari kandungan protein tepung ikan. Dengan dernikian perlu diteliti lebih lanjut untuk menentukan apakah kualitas atau kandungannya yang lebih berperan dalam proses pematangan gonad dan kualitas telur ikan napoleon. Hal yang sama menurut Tander et al. (1995) di mana fraksi protein dari tepung cumi berpengaruh nyata terhadap peningkatan kualitas telur gillhead seabream, Sparus aurata, yang diduga karena adanya keseimbangan komponen asam amino esensialnya. Ikan perlu makan untuk memenuhi kebutuhan energinya, sehingga energi pakan merupakan hal yang harus didahulukan daripada unsur-unsur lainnya dalam menentukan makanan yang masuk (feed intake) dan yang harus pertama dipenuhi. Oleh karena itu, jumlah energi pakan perlu diperhatikan, karena bila kebutuhan tidak dipenuhi maka jaringan tubuh akan dikatabolisme sebagai akibat dari keseimbangan energi yang negatif antara energi pakan dan pemakaian energi tubuh. Energi digunakan untuk keperluan di antaranya yaitu untuk pemeliharaan (maintenance) tubuh, misalnya metabolisme basal, pergerakan, pengaturan suhu tubuh, dan lain-lain (National Research Council, 1981).

Salah satu fungsi energi lainnya adalah untuk pertumbuhan dan produksi seksual/gonad (Smith, 1989). Umumnya ikan laut memerlukan energi/protein yang tinggi. Tetapi untuk pertumbuhan, keseimbangan antara unsur-unsur pakan adalah yang paling berpengaruh. Di samping energi, asam amino dan asam lemak mempunyai peranan yang penting dalam perkembangan gonad, sehingga pakan $A$ sumber proteinnya sedikit berasal dari cumi-cumi, pada pakan B sumber proteinnya seimbang antara cumi-cumi dan ikan sedangkan pada pakan $\mathrm{C}$ sumber proteinnya sedikit, berasal dari ikan, sehingga susunan asam amino pada pakan $\mathrm{B}$ dan $\mathrm{C}$ lebih seimbang, maka gonad ikan-ikan yang diberi perlakuan $\mathrm{B}$ dan $\mathrm{C}$ mampu berkembang dibandingkan perlakuan $A$

Dengan demikian keseimbangan antara unsur pakan yang berpengaruh terutama asam amino mempunyai peranan dalam perkembangan gonad. Waynorovich \& Horvath dalam Hardjamulia (1988) menyatakan pertumbuhan gonad terjadi jika terdapat kelebihan energi untuk turnbuh. Selanjutnya dikatakan bahwa defisiensi nutrien terutama asam amino, vitamin, dan mineral dapat menyebabkan perkembangan telur terhambat dan akhimya terjadi kegagalan ovulasi atau pemijahan.

\section{KESIMPULAN DAN SARAN}

Induk ikan napoleon yang diberi pakan dengan perbandingan sumber protein pakan dari tepung ikan dan tepung cumi-cumi 1:1 (perlakuan B) dapat memacu pematangan gonad, frekuensi pemijahan induk, serta meningkatkan jumlah telur.

Karena pada perlakuan pakan buatan perkembangan sperma tidak serentak dengan perkembangan gonad, maka perlu dilakukan penelitian kombinasi pakan buatan dengan tujuan memperoleh perkembangan gonad dan sperma dalam waktu bersamaan.

\section{UCAPAN TERIMA KASIH}

Penulis mengucapkan terima kasih kepada $A$. Gufron Arief, Ni Putu Ari Arsini, dan Ni Putu Ayu Kenak, Teknisi Litkayasa Balai Besar Riset Perikanan Budidaya Laut, Gondol, yang telah membantu dalam pelaksanaan penelitian ini.

\section{DAFTAR PUSTAKA}

Giri, N .A., Bejo Slamet, dan Tridjoko. 1999. Pematangan gonad dan pemijahan induk ikan kerapu batik Epinephelus microdon dengan perbaikan nutrisi pakan. Prosiding Seminar Nasional Penelitian dan Diseminasi Teknologi Budidaya Laut dan Pantai, Jakarta 2 Desember 1999. Pusat Penelitian dan Pengembangan Perikanan. p. 179--184.

Hardjamulia, A. 1988. Penyediaan induk untuk usaha pembenihan ikan air tawar. Prosiding Seminar Pembenihan Ikan dan Udang. 26 pp.

Mayunar, 1995. Pemijahan alami ikan kerapu macan Epinephelus fuscoguttatus, dalam bak terkontrol dengan berbagai perbandingan pakan ikan rucah dan cumi-cumi. Prosiding Seminar Hasil Penelitian 
Tabel 3. Frekuensi pemijahan, jumlah telur, dan gel. minyak pada ikan napoleon

Table 3. Spawning frequency, total number of eggs, and globula oil of napoleon fish

\begin{tabular}{|c|c|c|c|c|}
\hline $\begin{array}{l}\text { Perlakuan } \\
\text { Treatment }\end{array}$ & $\begin{array}{c}\text { Tanggal } \\
\text { pemijahan } \\
\text { Date spawning } \\
\end{array}$ & $\begin{array}{l}\text { Jumlah telur } \\
\text { Total number } \\
\text { of eggs }\end{array}$ & $\begin{array}{c}\text { Diameter } \\
\text { telur }(\mu \mathrm{m}) \\
\text { Eggs diameter }\end{array}$ & $\begin{array}{c}\text { Diameter } \\
\text { gel. minyak ( } \mu \mathrm{m}) \\
\text { Globe oil diameter }\end{array}$ \\
\hline \multirow{4}{*}{ A } & $09-3-2000$ & 75,000 & $665-689$ & $130-156$ \\
\hline & $10-3-2000$ & 30,000 & $656-676$ & $126-146$ \\
\hline & 15-3-2000 & 120,000 & $645-665$ & 124-145 \\
\hline & Total & 225,000 & & \\
\hline \multirow{13}{*}{$B$} & 14-12-1999 & 80,000 & $703-712$ & $140-156$ \\
\hline & $16-12-1999$ & 30,000 & $640-656$ & $125-140$ \\
\hline & $09-12-2000$ & 25,000 & $625-640$ & $125-140$ \\
\hline & $12-01-2000$ & 214,000 & $703-734$ & $156-172$ \\
\hline & $13-01-2000$ & 96,000 & $672-686$ & $124-142$ \\
\hline & 20-01-2000 & 30,000 & $656-587$ & $125-140$ \\
\hline & $07-02-2000$ & 35,000 & $674-704$ & $123-142$ \\
\hline & $08-02-2000$ & 60,000 & $652-656$ & $142-145$ \\
\hline & $10-02-2000$ & 85,000 & $634-687$ & $124-146$ \\
\hline & 09-03-2000 & 140,000 & $678-702$ & $140-150$ \\
\hline & $11-03-2000$ & 154,000 & $664-686$ & $130-142$ \\
\hline & 16-03-2000 & 135,000 & $645-678$ & $125-146$ \\
\hline & Total & $1,084,000$ & & \\
\hline \multirow{7}{*}{ C } & $13-12-1999$ & 75,000 & $640-703$ & $134-154$ \\
\hline & $20-01-2000$ & 80,000 & $642-689$ & $125-140$ \\
\hline & $06-02-2000$ & 110,000 & $645-668$ & $124-146$ \\
\hline & $08-02-2000$ & 120,000 & $654-676$ & $125-150$ \\
\hline & $17-03-2000$ & 96,000 & $643-687$ & $130-142$ \\
\hline & $20-03-2000$ & 120,000 & $654-680$ & $120-144$ \\
\hline & Total & 601,000 & & \\
\hline
\end{tabular}

Sub Balai Penelitian Perikanan Budidaya Pantai Bojonegara-Serang Cilegon, 11 Maret 1995. p. 84-89

National Research Council. 1981. Nutritional Energetics of Domestic Animals. National Academy Press, Washington, D.C.

Primavera, J.H. 1985. A Review of maturation in class thelicum penaeid prawns shrimp. In. Taki Y., J.H. Primavera, and J.A. Llobrera (Eds.) Proceeding of the First International Conference of Penaeid Prawns/ shrimps. EAFDEC Aquaculture Departement, Iloilo, Philippines. p. 18--22.

Slamet, B., Mayunar, S. Diani, P.T. Imanto, dan A. Supriatna. 1993. Pengamatan pada perkembangan pematangan induk ikan lemak Cheilinus yang diberi pakan ikan tembang dan cumi-cumi dengan perbandingan yang berbeda. Jurnal Penelitian Budidaya Pantai. IX(5): 91-.98.

Slamet, B, Hersapto, dan Tridjoko. 1999. Pematangan induk ikan Napoleon Cheilinus undulatus dengan pemberian jenis pakan segar berbeda. Dalam Prosiding Seminar Nasional Penelitian dan Diseminasi Teknologi Budidaya Laut dan Pantai, Jakarta 2 Desember 1999. Pusat Penelitian dan Pengembangan Perikanan. p. 253--256.

Shimeno, S., H. Hosokawa, Morie, M. Takeda, and M. Uka-wa. 1992. Inclusion of defatted soybean meal to diet for young yellowtail. Suisanzoshoku, 40(1): $51--56$.

Smith, R.R. 1989. Nuritional Energetics In. J.E. Halver (Editor), Fish Nutrition, $2^{\text {nd }}$ ed. Academic Press, San Diego, California, p. 2--29.

Takeda, M. 1981. Application of feeding stimulants for capture and culture fish. In Japanese society of Scientific Fisheries (Editor). Chemical Sense of Fish and Feeding Stimulants. KoseisyaKoseikaku, Tokyo. p. 109-118 (In Japanise).

Tandler, A., M. Harel, W.M. Koven, and S. Kolkovski. 1995. Broodstock and Larvae Nutrition in Giltbead Sea Bream, Sparus aurata. New findings on its 
mode of infolment in improving growth, survival, and swim infation. Bamidgeh, 47: 95--111.

Tridjoko, B. Slamet, T. Setiadharma, dan N.A. Giri. 1999. Perkembangan gonad dan pemijahan kerapu bebek
Cromileptes altivelis melalui peningkatan nutrisi pakan dan hormon. Prosiding Seminar Nasional Penelitian dan Diseminasi Teknologi Budidaya Laut dan Pantai, Jakarta 2 Desember 1999. Pusat Penelitian dan Pengembangan Perikanan. p. 195--200. 